\title{
Article 25. Financial Mechanism and Resources
}

1. In considering financial resources for the implementation of this Protocol, the Parties shall take into account the provisions of Article 20 of the Convention.

2. The financial mechanism of the Convention shall be the financial mechanism for this Protocol.

3. Regarding the capacity-building and development referred to in Article 22 of this Protocol, the Conference of the Parties serving as the meeting of the Parties to this Protocol, in providing guidance with respect to the financial mechanism referred to in paragraph 2 above, for consideration by the Conference of the Parties, shall take into account the need of developing country Parties, in particular the least developed countries and small island developing States among them, and of Parties with economies in transition, for financial resources, as well as the capacity needs and priorities of indigenous and local communities, including women within these communities.

4. In the context of paragraph 1 above, the Parties shall also take into account the needs of the developing country Parties, in particular the least developed countries and small island developing States among them, and of the Parties with economies in transition, in their efforts to identify and implement their capacity-building and development requirements for the purposes of the implementation of this Protocol.

5. The guidance to the financial mechanism of the Convention in relevant decisions of the Conference of the Parties, including those agreed before the adoption of this Protocol, shall apply, mutatis mutandis, to the provisions of this Article.

6. The developed country Parties may also provide, and the developing country Parties and the Parties with economies in transition avail themselves of, financial and other resources for the implementation of the provisions of this Protocol through bilateral, regional and multilateral channels.

Overview

As foreshadowed in the opening provision of the Protocol, appropriate funding is essential to achieve the objective of the Protocol - ensuring fair and 
equitable benefit-sharing, as well as contributing to biodiversity conservation and sustainable use. ${ }^{1}$ Financial solidarity - as an international obligation of intensified cooperation without expectations of reciprocity ${ }^{2}$ - is also a necessity in light of the fact that Parties with limited capabilities ${ }^{3}$ will be unable to comply with the obligations under the Protocol, particularly as they will face several complexities in developing domestic ABS frameworks. ${ }^{4}$ Limited implementation by developing countries will inevitably undermine the functioning of the international regime, which is based on the interoperability of domestic ABs frameworks, to the detriment of the entire community of Parties to the Protocol. ${ }^{5}$ For these reasons, financial solidarity embodies one of the expressions of the principle of common but differentiated responsibility. ${ }^{6}$ It thus serves as a 'test for the seriousness of efforts and willingness to cooperate' of developed countries ${ }^{7}$ as an equitable contribution to a common task. In practice, however, the qualified and open-ended formulation of international obligations on financial solidarity (in the Nagoya Protocol, as well as in other multilateral environmental agreements) may lead Parties to avoid systematic scrutiny at the multilateral level of compliance with relevant obligations. ${ }^{8}$

1 See this commentary on Article 1.

2 Campanelli, "Solidarity," op. cit., paragraph 17, and discussion of the obligation of solidarity in this commentary on Article 22, section 2.

3 This was clearly acknowledged in CBD Article 20(1), which reads: 'Each Contracting Party undertakes to provide, in accordance with its capabilities, financial support and incentives in respect of those national activities which are intended to achieve the objectives of this Convention, in accordance with its national plans, priorities and programmes.'

4 As acknowledged in Nagoya Protocol Article 22(4)(c).

5 Greiber et al., Explanatory Guide, op. cit., 221.

6 Rio Declaration, Principles 6-7. See generally Lavanya Rajamani, Differential Treatment in International Environmental Law (Oxford: Oxford University Press, 2006). For a discussion on the status of this principle in international law compare Ellen Hey, "Common butDifferentiated Responsibilities," in Wolfrum, Max Planck Encyclopaedia, op. cit., 444, who considers it a general principle of international law; and Christopher D. Stone, "Common but Differentiated Responsibilities in International Law," The American Journal of International Law 98 (2004): 276, 300, who concludes that it is not 'a customary principle of international law'.

7 Charlotte Streck, "Ensuring New Finance and Real Emission Reduction: A Critical Review of the Additionality Concept," Carbon and Climate Law Review 2011 (2011): 158, 159-160 and 168, in the context of the international climate change regime.

8 Francesca Romanin Jacur, "Controlling and Assisting Compliance: Financial Aspects," in NonCompliance Procedures and Mechanisms and the Effectiveness of International Environmental Agreements, ed. Tullio Treves et al. (The Hague: Asser Press, 2009), 435. See this commentary on Article 30. 
Against this background, Article 25, which is modeled after the Biosafety Protocol, ${ }^{9}$ addresses two issues: the provision of financial assistance through a multilateral financial mechanism established under the $\mathrm{CBD}$ - that is, the $\mathrm{GEF}^{10}$ and the provision of financial assistance by developed countries through other bilateral, regional and multilateral channels. ${ }^{11}$ In both instances, developed countries are the donors, and developing countries and countries with economy in transition are the recipients of financial support. ${ }^{12}$ The following sections will discuss the role of the financial mechanism under the Protocol, and the role of other forms of financial solidarity, in turn.

\section{$2 \quad$ Financial Mechanism}

The international governance of the financial mechanism under the Nagoya Protocol includes a key role not only for the Protocol's governing body, ${ }^{13}$ but also for the СвD Сор. The Protocol's governing body will provide guidance with respect to the financial mechanism as it relates to the Protocol, but such guidance will have to be considered by the СвD СОР. In addition, future guidance to be developed under the Protocol will have to take into account СвD COP guidance to the GEF adopted before the Protocol's entry into force. ${ }^{14}$ As a

$9 \quad$ Biosafety Protocol, Article 28.

10 Nagoya Protocol Article 25(2). See CBD Article 39; Nairobi Diplomatic Conference Resolution 1, "Interim financial arrangements" in "Nairobi Final Act of the conference for the adoption of the agreed text of the Convention on Biological Diversity" (1992), accessed 30 November 2013, <www.cbd.int/doc/handbook/cbd-hb-09-en.pdf>; СвD Decision 1/2, "Financial resources and mechanism" (28 February 1995) UN Doc UNEP/ $\mathrm{CBD} / \mathrm{COP} / 1 / 17$, paragraph 2 . For a discussion of the corresponding provision in the Biosafety Protocol, see Mackenzie et al., Explanatory Guide to the Cartagena Protocol, op. cit., 175. See Birnie, Boyle and Redgwell, International Law and the Environment, op. cit., 82-83; and Charlotte Streck, "Financial Instruments and Cooperation in Implementing International Agreements for the Global Environment," in Multilevel Governance of Global Environmental Change: Perspectives from Science, Sociology and the Law, ed. Gerd Winter (Cambridge: Cambridge University Press, 2011), 493.

11 Mackenzie et al., Explanatory Guide to the Cartagena Protocol, op. cit., 173.

12 СвD Article 20(2). Only the category of 'developed countries' has been defined for the purposes of financial resources and mechanism in the context of the СвD - and, by implication, its protocols - through a list adopted by the свр сор: Свр Decision 1/2, Annex II. See also Greiber et al., Explanatory Guide, op. cit., 222; and Mackenzie et al., Explanatory Guide to the Cartagena Protocol, op. cit., 174.

13 See this commentary on Article 26.

14 СвD Article 25(5). 
result, the policy of the $\mathrm{CBD}$ COP with respect to the GEF in relation to the $\mathrm{CBD}$ and in relation to the new requirements of the Protocol will be inextricably linked. ${ }^{15}$ It should be recalled, in that regard, that the G EF Council is obliged to 'act in conformity' with the policies, priorities and eligibility criteria decided by the CBD COP when acting as its financial mechanism. ${ }^{16}$ Consequently, the CBD COP is empowered to review the effectiveness of the GEF serving as the Convention's financial mechanism, ${ }^{17}$ thereby having an opportunity to hold the GEF accountable in its observance of the guidance provided by СвD Parties.

Article 25 also makes a link to capacity-building needs by cross-reference to the relevant provision of the Protocol. ${ }^{18}$ This can be interpreted so that in providing guidance to the GEF, the $\mathrm{CBD} \mathrm{COP}$, on the recommendation of the Protocol's governing body, will take account of the capacity-building needs identified in national capacity self-assessments by developing countries; and that in carrying out its role, the $\mathrm{GEF}$ will aim to meet the capacity-building needs so identified. ${ }^{19}$ This linkage with capacity-building is also noteworthy in recalling that under the Protocol capacity needs include not only those of Parties, but also those of indigenous and local communities, including women within these communities, ${ }^{20}$ as identified in national capacity self-assessments. ${ }^{21}$

Intergovernmental discussions preparing for the entry into force of the Protocol have already identified areas where guidance to the GEF is needed. Св Parties in particular recommended that financial assistance from the GEF be targeted to building Parties' capacity to develop, implement and enforce domestic ABS measures; ${ }^{22}$ supporting the negotiations of equitable and fair

15 As in the analogous provision of the Biosafety Protocol: Mackenzie et al., Explanatory Guide to the Cartagena Protocol, op. cit., 175-176.

16 Instrument for the Establishment of the Restructured Global Environment Facility as amended by Fourth Assembly of the GEF (24-28 May, 2010, effective 24 February 2011) 33 ILM 1283, paragraphs 15 and 26. Nonetheless, the relationship between the CвD СоР and the GEF may be more complex than may be suggested by this provision: see also CBD Decision 3/8, "Memorandum of understanding between the Conference of the Parties to the Convention on Biological Diversity and the Council of the Global Environment Facility" (11 February 1997) UN Doc UNEP/СвD/COP/3/38, Annex, paragraph 2.

17 свD Article 21(3).

18 Nagoya Protocol Article 25(3-4). See this commentary on Article 22, sections 2-3.

19 Mackenzie et al., Explanatory Guide to the Cartagena Protocol, op. cit., 175-176.

20 See Nagoya Protocol 1lth preambular recital.

21 Nagoya Protocol Article 22(3). See Greiber et al., Explanatory Guide, op. cit., 225. See also this commentary on Article 22, section 4.

22 Including through: identification of actors and legal and institutional expertise for the Protocol's implementation; taking stock of domestic measures relevant to ABs in light of 
MAT, ${ }^{23}$ including through enhanced understanding of business models and IPRs; and developing endogenous research capabilities in provider countries to add value to their own genetic resources and associated traditional knowledge. This is to occur through, inter alia, technology transfer, bioprospecting and associated research and taxonomic studies, and the development and use of valuation methods. ${ }^{24}$ Furthermore, the GEF is mandated to finance projects that will assist in addressing the capacity needs and priorities of indigenous and local communities and relevant ABS stakeholders, such as through the development of community protocols, model contractual clauses and minimum requirements for MAT to secure fair and equitable sharing of benefits. ${ }^{25}$

Even before the entry into force of the Protocol, СвD Parties have had an opportunity to hold the GEF accountable in supporting preliminary ABS activities aimed at speeding up ratification of the Protocol. This occurred in relation to the Nagoya Protocol Implementation Fund ${ }^{26}$ - a multi-donor trust fund that started operations in May 2011, managed by the GEF and operated by the CBD Secretariat. The Nagoya Protocol Implementation Fund supports not only signatory countries and those in the process of signing the Nagoya Protocol to accelerate their ratification and implementation of the Protocol, but also the private sector in developing and implementing concrete ABS agreements, with a view to exploring the economic potential of ABS transactions and facilitating technology transfer. ${ }^{27}$ The latter was thus meant to achieve the aim of generating additional information to help understand future Parties' capacities and

the obligations of the Nagoya Protocol; establishing ways to address transboundary issues; and establishing institutional arrangements and administrative systems to provide access to genetic resources, ensure benefit-sharing, support compliance with PIC and MAT, and monitor the utilization of genetic resources and associated traditional knowledge, including support for the establishment of checkpoints. See ICNP Recommendation 2/1, "Elaboration of guidance for the financial mechanism," Annex I, paragraph 1 in ICNP, "Report of the second meeting," UNEP/CBD/COP/11/6, Annex. See this commentary on Articles 11 and 13-18. Note, however, that Article 17 does not foresee monitoring of the utilization of traditional knowledge: on this point, see this commentary on Article 16, section 3.

23 See generally this commentary on Article 5 section 5; and also on Article 6, section 7 and on Article 18.

24 ICNP Recommendation 2/1, Annex II, paragraph 1(c).

25 See this commentary on Articles 12 and 19.

26 "GEF Establishes the Nagoya Protocol Implementation Fund," СвD (3 June 2011), accessed 30 November 2013, <www.cbd.int/doc/press/2011/pr-2011-06-03-GEF-ImpFund-en.pdf>.

27 Compare: "Nagoya Protocol Implementation Fund," World Bank, accessed 30 November 2013, <http://fiftrustee.worldbank.org/index.php?type=fund\&ft=npif>. 
needs in relation to effective ABs transactions. ${ }^{28}$ During intergovernmental discussions preparing for the entry into force of the Protocol, however, CBD Parties raised concerns about the use of the Fund to support the private sector's engagement in ABs transactions, despite Parties' prioritization of support to governments in ratifying and implementing the Protocol through the development of national legislation and consultations with national stakeholders to that end. Financial support for private sector's engagement in ABs transactions before the entry into force of the Protocol thus raised issues related to diverging priorities set under the GEF, on the one hand, and under the CBD and its Protocol, on the other. ${ }^{29}$ This discussion also showed the potential for vested interests in favoring ABS transactions while provider countries have not yet developed the necessary national ABs frameworks and guarantees for indigenous and local communities. The Intergovernmental Committee preparing for the entry into force of the Nagoya Protocol therefore emphasized the need for the GEF to provide funding as a priority to law-making and related preparatory activities at the national level. ${ }^{30}$

\section{Other Bilateral, Regional and Multilateral Channels for Financial Resources}

In voluntarily providing financial resources through other channels, developed countries are to take into account the needs of developing countries, as

28 See "Nagoya Protocol Implementation Fund Brochure," GEF, accessed 30 November 2013, $<$ www.thegef.org/gef/content/nagoya-protocol-implementation-fund-brochure $>$. See also Greiber et al., Explanatory Guide, op. cit., 224.

29 Instrument for the Establishment of the GEF, paragraph 25(c)(i) reads: 'decisions requiring a formal vote by the Council shall be taken by a double weighted majority; that is, an affirmative vote representing both a 60 percent majority of the total number of Participants and a 60 percent majority of the total contributions.' However, it has been argued that the GEF's voting structure 'does not preclude the possibility of conflict between the objectives of the Conventions, the implementing agencies, and the GEF in the context of particular decisions.' See Jacob Werksman, "Consolidating Governance of the Global Commons: Insights from the Global Environment Facility," Yearbook of International Environmental Law 6 (1996): 27, 60, and discussion in Birnie, Boyle and Redgwell, International Law and the Environment, op. cit., 83.

30 ICNP Recommendation 2/1, Annex II, paragraph 3, integrated in COP Decision XI/5 (Financial mechanism). ENB 9/579, "Summary of the Second Meeting of the Intergovernmental Committee for the Nagoya Protocol," 15. 
identified in their capacity need self-assessments, ${ }^{31}$ and may choose between bilateral, regional and multilateral channels. ${ }^{32}$ It remains to be clarified, however, to what extent the relevant provisions of the $\mathrm{CBD}^{33}$ are to be 'taken into account' under these circumstances. It may be understood that the CBD provisions on financial solidarity do not directly apply to the provision of financial resources under the Protocol, so arguably potential donor countries are not obliged to provide financial resources, but merely to consider the need for financial resources. ${ }^{34}$ It has also been suggested that not all provisions of СвD Article 20 are equally relevant for ABs, but they should be considered to the extent that they have a bearing on this issue. ${ }^{35}$

If bilateral financial assistance is provided in the context of bilateral agreements, these are to be negotiated and implemented in ways that ensure the achievement of the objective of the Protocol. ${ }^{36}$ Even outside of these treatybased arrangements, however, unilateral and bilateral financial support for the development of domestic ABs frameworks in developing countries needs to be demand-driven and responsive to the particular needs and circumstances of the receiving country, to avoid allegations of undue interference with national sovereignty. Clearly financial support for these activities will occur not only in the interest of the international community in the effective implementation of the Protocol, but also in developed countries' own interest (to ensure predictability and fairness for their users). The delicate, and in many respects still open-ended, balance of international obligations enshrined in the Nagoya Protocol may thus create a risk that unilateral and bilateral financial solidarity initiatives supporting the implementation of the Protocol may undermine the partnership between user and provider countries to be established under the Protocol. Such a risk may arise if undue influence is exercised or pressure is put on provider countries' exercise of their national sovereignty over their genetic resources and on indigenous and local communities in that context. ${ }^{37}$

$31 \quad$ Nagoya Protocol Articles 25(4) and 22.

32 Nagoya Protocol Article 25(4).

33 Nagoya Protocol Article 25(1).

34 For an analogous interpretation of the corresponding provision under the Biosafety Protocol, see Mackenzie et al., Explanatory Guide to the Cartagena Protocol, op. cit., 175.

35 Greiber et al., Explanatory Guide, op. cit., 223, who do not, however, elaborate on which СвD provisions could be considered less or not relevant in the context of the Protocol.

36 See this commentary on Article 4, section 3.

37 The issue was preliminary discussed in Morgera, "Bilateralism at the Service of Community Interests?", op. cit., 760-763. 
Intergovernmental discussions preparing for the entry into force of the Protocol have already identified the need to take a strategic approach to maximize opportunities for financial support as a complement to the GEF. A recommendation is thus made to integrate the provision of financial needs under the Protocol into the CBD Strategy for Resource Mobilization. ${ }^{38}$ In addition, Parties are encouraged (i.e., they are to remove barriers at least, and/or to create incentives ${ }^{39}$ to direct domestic resources, including those generated through the successful implementation of ABS agreements, towards the implementation of the Protocol. ${ }^{40}$ Governments, organizations, the private sector and financial institutions are encouraged to provide financial resources, including through new and innovative financial mechanisms, for the implementation of the Protocol. ${ }^{41}$

38 свD Decision 9/11 "Review of implementation of Articles 20 and 21." The Strategy was adopted in 2008 to achieve multiple aims, including to improve the information base on funding needs, gaps, and priorities; strengthen national capacities for resource utilization; strengthen existing financial institutions; explore new and innovative financial mechanisms; to build capacity for resource mobilisation and promote SouthSouth cooperation as a complement to North-South cooperation; and enhance the global engagement for resource mobilisation.

39 On the obligation to encourage, see this commentary on Article 9, section 1.

40 ICNP Recommendation 2/2, "Guidance for resource mobilisation for the implementation of the Nagoya Protocol on Access and Benefit-sharing" in ICNP, "Report of the second meeting," UNEP/CBD/COP/11/6, Annex, paragraph 3. cop Decision 11/5, "The financial mechanism" (5 December 2012) UN Doc UNEP/CBD/cop/11/35, paragraphs 21-23.

Ibid. 